DOI https://doi.org/10.36059/978-966-397-110-0/102-123

\title{
CIVILIZATIONAL CHOICE OF UKRAINE IN 1917-1920: REASONS AND IMPLICATIONS
}

\section{Popov V. Z.}

\section{INTRODUCTION}

The study of the structures of everyday life in the past makes possible to evaluate the present day in a different way, its precipitance, and at the same time its connection with other similar days. Each of these days is not an accident, but an integral part of the whole cultural tradition. On the other hand, studying the history of everyday life lets you see the typology where it is most difficult to see, i.e., in specific decisions made in various situations. And then it turns out that history repeats itself because we are changing slowly- not abstract, virtual social structures, but exactly we are, the living people. The history of everyday life proves that people do not move along the same rut, and therefore the inductive path - the path to comprehending the common (ideas about the world of a group of people or the whole society) through an individual (the lives of individuals) - is a very productive way of recreating the life of past centuries.

The category of everyday life includes the scope of public everyday life events, above all, the small private events, during which the people are looking for a ways to adapt to the events of the external world. Everyday life includes all kinds of circumstances of private domestic life, daily routine life in its sense, as well as the emotional side of events and phenomena, the experience of everyday events and everyday circumstances by individuals and groups of people. In a broad meaning, our daily life is an activity to satisfy our needs, the nature of which and the possibility of realization depend not only and not so much on ourselves, but on the nature of the epoch and the level of the socioeconomical development of society.

Extreme events disrupt the course of everyday life, although experiencing these events refers to the daily being. However, the recurrence of extraordinary events introduces them into the circle of usual phenomena. An unusual lifestyle, which is not repeated by anyone, can be considered a daily practice for certain categories of citizens. 
In the paradigm of the history of everyday life, there is a wide range of possibilities for exploring the specifics of the conception of everyday needs by contemporaries of profound social changes. In the conditions of the political crisis of the Ukrainian society in 1917-1920 citizens tried to keep their lives ordinary in not ordinary conditions, sometimes choosing the most unexpected ways and means. The history of everyday life in this case includes the forms of human behavior in specific conditions, and the survival strategies chosen by them. An extraordinary changes made a normal existence to be a kind of rare privilege. It was a survival that gradually became the main motivation of human behavior. The informative side of survival was the desire to preserve the usual way of life.

Society developed primitive responses to its needs. In extreme conditions, there were certain changes in the behavior of people. In such conditions, people became puppets, who were tugged by real players, which could be biological instincts, economic processes, external orders, results of socialization. And the result of such changes for the further development of society could be completely unexpected.

\section{The impact of the social crisis of 1917-1920 on the everyday life}

The modern period of Ukrainian history began with the proclamation of the state independence. The first years of state-formation were accompanied by numerous crisis phenomena that directly affected both the society as a whole and its individual layers, and each individual person. Serious experiences endured by our people at the end of the last century brought contemporaries back to the history of its first decades. The actualization of historical memory was due to fact that in the conditions of the restructuring of all spheres of public life, an ordinary citizen had to make a great efforts in realization of his ordinary needs, sometimes that efforts were not less than his compatriot made during the revolution and civil war. In this regard, the experience of previous generations allowed to make a new look at the problems of the present stage of historical development. The consequences of the systemic crisis of 1917-1920 and the nature of the changes that occurred during these years have became a part of our cultural code, and are still affecting the modern Ukrainian society.

The destruction of the usual world, the traditional society and the state led to the devaluation of the values on which the human world of the 
previous historical era was based. This process opened the way for a new social reality, which in turn changed all aspects of the existence of an ordinary person and his social environment. The tremendous changes led, among other things, to the disorientation of individual and collective mind. The revolution radically changed social life, which acquired new meanings, and assumed forms that did not exist before.

Under the conditions of a systemic social transformation, the daily life of an ordinary person acquired a special meaning. By tradition, it included a description of a person's position in society and a social group, his needs and the possibilities of their achievements. The concept of everyday life included an individual and collective practices, as well as customs and traditions regulating people's behavior. It included forms of communication, experiences, norms, habits.

Changes in everyday life of ordinary citizens were more intermediated. At the first sight, it was outside of big politics, was an antipode of historical cataclysms. At all times everyday life had a certain degree of autonomy, a strongly marked inertial character, and it tried to protect itself from the pressures of social processes. Any contemporary tried hard to keep the privacy of his own little world. The growth of crisis phenomena has narrowed the people's view of the world. But political events took place on the background of everyday life, in this conditions human destinies were realized. The everyday life was a basic need for human activity, it was a background of the socialization of each person, including a political activists. It reflected all the diversity of social relations that existed in society. It became a link between private and public interests, between routine life and working, between behavior of each individual and events of national importance.

Everyday life in a conditions of a social catastrophe was deprived of its fundamental features. The settled, normative everyday life acquired signs of extraordinary and extreme. In the realities of civil confrontation, fixed in people's minds patterns of behavior based on common sense and life experience, had stopped. Usual algorithms of solving the problems had failed. Daily routine and monotony, so prevalent in usual human being, became an unreachable fantasy. Every new day put a person in front of the need to search for non-standard ways to solve trivial tasks. Realization of needs and interests always appeared to be a personal 
choice. In an era of crisis, the choice became fateful, life has literally depended on its correctness.

Each historical era formed its own rules of human behavior. Prohibitions and permits were formulated, thereby the borders between the norm of human existence and unacceptable deviation from the norm were established. The features of everyday life depended on the level of human needs and abilities, and was determined by cultural restrictions of a certain social group, cultural normative of a particular era. In 1917-1920 most of the prohibitions were lifted, the line between the norm and pathology became unclear, relative. The level of culture of different social classes was equalized. The daily routine of each era has its own subjective feeling of time. The time acquired an extremely compressed character due to the speed of revolutionary changes. In everyday life, a person daily met with repeated events, processes, deeds. But the conditions of daily human existence were changing so rapidly, and this rapidity was intensified by people's emotional reaction to the changes that were taking place.

The daily life of the population of large cities during crisis acquired a special character. Cities as a product of civilization died as well as the normal life. For urban people, implementation of both sides of everyday life, both technological and mental, was extremely difficult. A lot of efforts and wonders of ingenuity had to be applied to find out the ways to meet everyday needs - what to wear and where to live, how to move, what to use in work, education and leisure, how to take care of health. On the other hand, it was difficult for the townspeople to find a new semantic content for their life, to work out a system of life guidelines - how and why to live, what values to follow, what moral principles to adhere to. The past habits, priorities, tastes was gone. On the peasants social changes were reflected less. The traditionalism of rural labor and life, relative detachment from power, closeness to the land as a source of rescue made the village an island of economic stability and political inertia.

A feature of the revolutionary era and civil war was an appeal of political military figures to global concepts and categories. They made history, they decided the fate of countries and peoples. The characters of the historical drama were classes, nations, states. The destinies of some contemporaries of events were lost in their confrontation. Ordinary citizens, for whom, according to political declarations, this long-term struggle has been started, often did not understand what was happening in 
the country. The disaster, which broke their insular world, put the inhabitants in front of many new and unexpected realities. They once found out that the united country in which they were born and raised, no longer exists, it disappeared without voting and referendums. The periodically changing power was of a usurping nature, and did not carry any sign of legitimacy. Information about the events taking place in the country was, most often, fragmentary, controversial, unreliable. A city dweller could only believe what he saw with his own eyes - lines in stores, prices in the nearest market, spontaneous meetings, crowded train stations. Armed strangers, sometimes dressed in uniform, and more often wearing anyhow, could enter private houses. On a street known since childhood, a lot of dangers could be waiting for a passerby, and it was not known whom to complain and ask for help. Rumors, which were one more fantastic than the other, taught people not to trust anyone or anything but their own impressions. Nevertheless, the relentless law of life forced them to join the struggle not for political ideals, but for their own existence. In this struggle, many destinies ended tragically. Majority of survivors joined the winner side.

The question of how and why they survived, what is the main reason for their final choice, has not yet been the subject of attention of researchers. The history of the "little person" of the great time has not yet been written. Meanwhile, the transformations of human conception, due to the specifics of everyday life in 1917-1920, was a factor which determined the nature of the political, economic, social development of the country and society for next decades. Through the everyday life we can more deeply understand the content of a person who participated in the political events of 1917-1920, that's why reference to the history of everyday life is fully justified and necessary.

\section{Transformations of urban everyday life}

The nature of everyday life and work in 1917-1920 determined by the general situation in the country. Everyday life was depended on the logic of civil confrontation and political cataclysms. It was subjected to certain restrictions, regulations and political control. The spring of 1917 for the urban population became a time of great hopes, the human interest in politics increased. Thus the greater was the disappointment. In the autumn 1917, apathy became the dominant political mood among the citizens. 
Unfulfilled expectations caused mistrust to an authority. The other side of indifference and apathy was a political extremism. Separate groups of the population, first of all demobilized soldiers, sought to immediately satisfaction of their needs. The struggle for existence by frustrated citizens of a "failed to become free" country denied them of any political engagement. Since spring of 1919, all kinds of public street speeches had stopped - not only political, but also economic. They were replaced by ordinary workers' strikes due to material motivations. Throughout the revolution and the civil war, the attitude of the urban population towards the leaders was characterized by three different approaches. A person sought either to become a leader in order to use all possible preferences at the moment, or to ask the current ruling authorities for help in solving his everyday problems, or to distance himself as much as possible from the authorities which prevented him from maintaining his usual lifestyle. Moreover, all these three behaviors could be seen under any of authorities.

The solution of everyday problems, which individual could not manage himself, started to be done by different social groups. These were associations based on gender, professional, ethnic, national, territorial attributes. The main types of public associations were trade unions, cooperatives, consumer companies, social, cultural, educational and sports organizations, mutual aid societies, and self-relates establishments in public education.

There was a spreading of "meetings democracy". Meetings were supported by public institutions, which did a formulations to requirements of the participants and referred these formulations to the relevant authorities. With an uncertain quantitative and qualitative composition, their power was truly unlimited. The meeting's democracy ended after the establishment of power of the Central Rada in the spring of 1918.

The formation of various associations of city dwellers was caused by need of society to assume the functions of government on the one hand, and on the other - by need of citizens for protection. These associations were represented by various groups. For example, trade unions had been created almost in every manufacturing department.

The issues that were solved by public organizations can be divided into three groups. The first was assistance and mutual help to socially disadvantaged groups, and providing of meaningful activities. The society in general worked out with these tasks independently. The second group 
included the protection of the rights of citizens, including ensuring their safety, and the provision of education. Here, social activists sometimes had to be supported by the power of the political system. Finally, the third group included sanitary-epidemic measures and ensuring the manufacturing process. In these problems, state organizations owned an undisputed priority. Repeated military operations, frequent change of power, the collapse of the economy led to the fact that at the end of 1920, public organizations experienced a serious crisis.

It is hard to accept the statement of M.V. Borisenko, that the house committees and their chairmen turned into full and uncontrollable owning of houses, that all residents feared them, regardless of their social origin ${ }^{1}$. Particularly during the periods of Bolshevik's government in Ukraine, the chairmen of the house committees, no matter how respected they were, were threatened with immediate punishment if the tenants failed to comply with the absurd orders of the new government. It is also impossible to agree that the standard of living of the population of small towns has crossed the lower limit of the resumption and preservation of the population. In small towns the chance to survive was higher than in megacities due to the proximity to the land.

The main feature of the attitude of the population to participants of the civil war was the lack of fear of urban inhabitants in front of them. Hiding from artillery and machine-gun fire, the townspeople solemnly, or at least, curiously greeted the next army. Since there was never a clear front line, there were quite a few adventurers crossing the combat zones in all directions. The threat of accidental death has always existed, but it was rather hypothetical, and the threat of death from hunger and cold remained real with all the authorities, so people took the risk to get food or prepare fuel for the winter. A man with a gun could be both a source of danger and a guarantee of security, depending on the ability of specific members of the civilian population to build relationships with him.

Not quite right, in our opinion, I.N. Shklyaev, who believed that Odessa always passed from hand to hand without a fight, with "few" shots $^{2}$. At least in the winter and spring of 1918, during the battles of the Ukrainian army, respectively, with the Bolsheviks and the White Army,

\footnotetext{
1 Борисенко М. В. Житло та побут міського населення України у 20-30-х pp. ХХ століття. - К.: ВД «Стилос», 2013. - С. 255.

${ }^{2}$ Шкляев И. Н. Одесса в смутное время. - С. 136.
} 
the fightings were long, cruel, and were accompanied by active participation of the civilian population.

The preservation of the level of civilization was closely interrelated with the tasks of survival of society in conditions of chaos. And if there was or was not any kind of power in a particular place, everyday interaction between people was carried out mainly in traditional forms. The feature of everyday life in extreme conditions was social inertia, manifested in the ability of social structures and individuals to maintain the usual forms of interaction in a changing situation. This quality of everyday life was supported by social autonomy, that is, by the ability of social structures to carry out their tasks, regardless of the administrative actions of the authorities, or even without them. These structures, first of all, were utility services of the municipal government, education, medicine, transport, trade, and some other social institutions.

If you try to determine the level of ability of social institution to organize itself, then the best examples would be an education and health care which had the maximum autonomy. Educational institutions, as well as medical institutions, were created and maintained during the years of the revolution and civil war by local governments, local professional organizations, charitable foundations, and private individuals. Both of them could not completely distance from the political sphere, although they strongly emphasized their non-political nature. Statement of I.V. Narskoy ${ }^{3}$ about the destruction of traditional bases of socialization in Russia in 1917-1920, in relation to Ukrainian realities is only partly true. Schools and hospitals worked during all political regimes. But they had to ask for help from the government in case of violation of their rights from another sides. It was the human rights sphere that remained the prerogative of the state, or structures that positioned themselves as state ones. By the way, such structure could be any armed squad. The social sphere was falling into decay without sufficient funding, since even charitable assistance could be carried out only in conditions of a stable economy. The transport, with all the facts of being an independent organization, was too dependent on technical support, which, in turn, could not be provided sufficiently in the conditions of a crisis.

A personification of social institutions had a specifics of a social functioning as a structure. General norms ceased to operate, and the C. 588.

Нарский И.В. Жизнь в катастрофе: Будни населения Урала в 1917-1922 гг. - 
activity of most spheres of public life was transferred to the competence of certain individuals, who, despite a lot of problems, continued to follow their duties. Therefore, the quality of medical care or educational services was depended not only on the solvency of consumers, but also on the qualifications, integrity and dedication of the people who provided these services. This explains the presence of hospitals and schools that worked throughout the civil war, whereas there were many institutions that very quickly stopped their activities.

In the daily life of cities in Ukraine in 1917-1920 there were numerous signs of such a socio-psychological phenomenon as a social revenge. Representatives of the high class of the urban population were forced to get used to the lifestyle of the lower classes. First of all, it was demonstrated by changes in the kinds of food. The intelligentsia, which included lawyers, teachers, doctors, had a limited food consumption, which was mainly plant products. At the same time, workers and small entrepreneurs who have not lost contact with the village, for a long time could afford meat and other animal products. However, this situation persisted only until 1919, when the character of food of all urban classes became approximately the same.

As a second sign of social revenge could be considered a change in the appearance of yesterday's "owners of life". They took off their uniforms, coats and hats, and maximally democratized their outer clothing. Previously depressed people started an extensive use of clothes and things confiscated from the rich people, including underwear, as well as clothes exchanged for food. Thus, the situation on the city streets resembled a kind of overall carnival, when no one wore their own clothes, and people massively donned someone else's clothes.

The third type of revenge should include the loss of old, familiar, cozy furniture and other household utensils. The furniture was actively confiscated by the Bolsheviks, who took away a lot of tables, chairs, cabinets, and at the same time bed linen, wall clocks, musical instruments and other household utensils. Finally, the furniture was transferred under the management of the new government, and filled up an empty places there. Furthermore, furniture that people saved from confiscation, was burned down in the stoves during the long years of war. Beds, baths and more other things went for the hospital appliances. The townspeople were 
forced to huddle two in one, or three in two beds, or even to sleep on garden benches, tables, or simply on the floor.

Deliberate change of appearance, as a way to dissolve in a democratic environment, can be called social mimicry. That was the dressing of high-ranking townspeople in simple clothes, and the officers in soldier overcoats. The simplification, the abandonment of bourgeois habits, such as taking care of their external appearance, were one of the survival techniques. Deliberate untidiness of former intellectuals, who tried to merge with the crowd of proletarians, was another sign of the "carnival". A change of social affiliation could be considered as a type of mimicry as well, to which resorted not only the former privileged class of people, but also the proletarians of yesterday. Former hand-workers, when they became a Soviet employees, simply "commissars", categorically refused to provide services in their previous work to those in need of assistance. The city dwellers from the highest groups who were not engaged in speculation, had to earn a living by unskilled labor, which did not require a special preparation. They served as a waiters, couriers, peddlers, order takers, firewood sawyers. By the way, for a long time there was such a field of activity as domestic servants. The institution of servants survived during all regimes, including two Bolsheviks' regimes, and ceased to exist because of the impoverishment of employers, but not because of the struggle for universal equality.

Social antagonism has became so acute that the class hatred reached a signs of social racism, that is, perception of members of another social group as being of a lower priority. This could be expressed in irritation about the appearance - too clean and well-groomed in one case, and too neglected and untidy in the other. The saddest thing was that this attitude was linked in minds of the inhabitants of both groups with the prospect of retaliation. In this phenomenon were the psychological roots of civil war.

Another type of deformation in the psychology of urban inhabitants was a change in their attitude towards the arrival of the new government. At the first stage of the revolution, the leaving of one army and the coming of another were often accompanied by panic attacks, there were fast transitions from depression to euphoria and back. Moreover, the polar feelings took possession of various social classes, caused by their interests which armed force will protect them in the future. In 1920, panic as a state of mass consciousness disappeared, on the eve of the change of power, the 
urban population remained completely calm. Inspiration and enthusiasm disappeared from the palette of public sentiment in the urban environment. The loss of external signs of culture was accompanied by an internal suffering, mental trauma.

Legal regulations stopped to operate. The previous were abolished, and the new ones had not yet been accustomed. Therefore, problems were solved not by law, but by acquaintance, and people who had some useful acquaintanceships, same as the money, were taking care by themselves, avoiding using it at the request of others.

The authorities and local governments tried to introduce a rationalized distribution of public services - particularly the electricity and water, and in extraordinary situations they applied emergency measures to employees of the relevant services. They sought to provide construction, utilities and other needs - such as garbage collection, street cleaning, lighting, heating. Private trade, handicrafts, and cooperatives had persisted.

Residents of the cities showed extraordinary diligence, energy and ingenuity in finding sources of lighting and heat, in providing food for themselves and their families, in preserving human relationships and human appearance.

People continued to do traditional things - they were taking care of their homes, teaching children, going to the hairdresser, sewing new clothes and shoes and re- sewing old, making homemade soap, with all their mights were solving problems of heating and lighting, renting and renting out houses, and were using the pre-war stocks of matches, soap, salt, kerosene, light bulbs and other.

The history of the revolution, of course, contains examples of the opposite nature, especially at the final stage of the revolution, when the stocks of food did not meet the needs of people, and the results were exhaustion, illness, mental disorders. The strength, accumulated in the urban environment, was quite high. For example, in the autumn 1920 in the Donbass, in spite of numerous political and military changes, citizens saved a significant part of the pre-war property - as a furniture, books, musical instruments, and even clock which was still working. The market had continued active exchange of clothes and other things for food. However, the condition of the cities reached catastrophic, the possibilities 
for survival were almost exhausted, and for this reason, the new rulers were forced to decide on a transition to a new economic policy.

There were deep deformations of the world around. The usual signs of peacetime have disappeared - well-groomed parks with garden benches, clean streets, well-functioning public transport. The urban environment has been destroyed starting from the big to the small. First began the destruction of usual appearance of parks, squares and streets. In addition to the destruction of green spaces, the facades of houses and street cover were damaged, old monuments were replaced with new ones, usual posters were covered by a revolutionary posters. Unauthorized garbage dumps appeared, first outside the courtyards, then inside the courtyards. Finally, the interior spaces of houses and apartments were cluttered, so, the basis of the internal space was destroyed. Cold houses, lack of communal amenities, the need to do household in improper conditions, all of these factors deprived people their usual comfort. The need forced to abandon a lot of useful and cute things in life, in exchange for food. Home libraries disappeared from the apartments, the books were either for kindling or for sale. Bolshevik's requisition completed the case. Having lost all the outward signs of urban culture, people lost their urban lifestyle, and turned into seekers of a piece of bread and firewood, which meant a loss of social identity.

\section{New Priorities for Meeting Needs}

The crisis has put society in front of the necessity to rigidly determine priorities in meeting the needs. And in particular, the issue of food supply of population remained strategically important throughout the civil war. In 1917-1918 in addition to centralized supply, private trade was actively functioning, and there was a serious difference in prices for products between geographically closed regions of Ukraine. This fact prompted many citizens to search for cheaper food.

Separate categories of the population faced hunger as early as 1918, large cities found themselves in a food blockade in the winter of 19181919. The workpeople were suffering from malnutrition during all ruling authorities, and starved under volunteers too. Residents of the cities found solutions in earnings in the countryside, in the exchange of their poor property for bread, in the gardening. An additional way to be saved from the hunger death was public catering. During the Bolsheviks period, a 
network of canteens developed, and were providing the scanty meals to those who need. A characteristic feature of psychology at that time was the reduction of threshold of disgusting, when hunger didn't let people notice the unacceptable sanitary conditions of the dining room, the low calorie content of the dishes offered, the terrible condition of the products that were used for the preparation. Clothing stopped to be a determinant of social status, new clothes were stopped being sold, the only way to get a new dress was to buy a military uniform. For the rest, the secondary clothing market was successfully working. The society still was in need of a numerous services, and they has been provided by professionals of the corresponding profile, depending on the ability of people to pay.

A.A. Ilyukhov is wrong when he claims that during a civil war there was no such service as public catering, and that the proletarians had nothing to sell on a flea markets ${ }^{4}$. The canteens in the Ukrainian provinces gave many poor citizens a chance to survive, while the workpeople, wearing rags, carried the last property to the market.

The necessity to obtain up-to-date information became a kind of primary need for the population. Knowledge of the prospects of the current government and the possibility of onset of political changes caused the start of planning of specific actions, firstly, to choose behaviors aimed at ensuring one's own security, and, secondly, to create at least minimal food reserves. Therefore, ordinary citizens were greedily catching every printed word, were eagerly awaiting another batch of news, and in the absence of newspapers they heard various rumors, sometimes completely unbelievable, but sometimes more accurate than official press reports. In addition, ignorance of the instructions of the authorities could have resulted in the worst consequences, though the references to the inaccessibility of printed materials would not help. In these cases, rumors were helping, however, sometimes making a panic worse, but more often they were confirmed.

The failure of established system of values was accompanied by the formation of a new morality and ethics. Human life has been devalued, becoming a convenient field for social experimentation. Violence was absolutized, it was elevated to the cult by all military-political parties. The value of life has fallen below the lower limit, in fact, murder has became as commonplace as, for example, a robbery. The list of threats to the

\footnotetext{
${ }^{4}$ Ильюхов А.А. Жизнь в эпоху перемен: Материальное положение городских жителей в годы революции и гражданской войны. - С. 86.
} 
average person was expanded, the risk of being a victim of an attack increased to the maximum.

The methods of individual and collective salvation from criminals were not diverse. The person in the street has always sought to hide, to isolate himself from danger. The documents contain only few facts of the use of weapons by civilians against bandits. Firstly, people simply did not know how to handle weapons, and secondly, armed resistance could end badly, and the lack of resistance gave a chance for salvation. From a real attack, home-guard could protect only with the help of people from other houses and areas. Workers groups were the most militant. In addition, as in any other field, professional guards succeeded in protection. Of course, most of them in the winter 1918-1919 turned out to be part of different armies, but episodes of providing of paid security services were taking place until the end of active armed operations.

During the war, a prevalent phenomenon was the creation of selfdefense detachments, functioning either parallel with the so-called governmental detachments, or, in some regions, existing independently. The organization and activity of overlapping defensive enforcement structures created a certain tension between them, sometimes leading to direct conflicts. The local population was ready to bear the material costs for the sake of at least relative safety. Practically with any authority, selfprotection was self-financial, that is, it was payed for by citizens. Acquisition of security was carried out in various ways. Firstly, security functions were performed in turn by residents of houses. Secondly, working collectives were choosing their most reputable representatives to protect. Thirdly, periodic mobilizations were carried out, either by the authorities or by self-appointed initiators. Finally, there were squads of voluntariness.

The composition of guard groups depended on the kind of authority. The Soviet institutions preferred to involve the former front- line soldiers, workpeople - preferably miners and metallurgists, and the poorest farm workers. The White Guards sought to rely on small and medium owners living in the city and village - homeowners, merchants, wealthy peasants. Groups and detachments of law enforcement also included retired officers, students, high-school students, intellectuals, declassed elements, and former criminals. Central authorities, local governments, political and public organizations, and house committees were responsible for the 
creation of security groups. On the territories with population mainly engaged in industrial work, self-protection was created at mines and factories, in the countryside - by a common peasant meetings. Ways of armament were also very diverse. Local councils, army units were providing the weapons, which was confiscated from social opponents, as well as it could be confiscated from the invaders. Usual hunting rifles were used. The documents do not contain information about the use of weapons brought by former front-line soldiers. Indirectly, there is an evidence of its presence among the population, and there are facts that while authorities were arming the guard groups, at the same time they were trying to fight with uncontrolled possession of weapons, sometimes with very tough measures.

Self-defense squads were performing numerous functions, which include the fight against speculation, ensuring discipline at public events, protecting their communities from gangsters (red, or white, or green though), detaining opponents of existing power, suppressing riots, preventing shambles.

Security was provided at the level of the city, district, quarter, separate house. The security groups were hired by both homeowners and ordinary citizens. Security was always created in response to the increased threat of criminal encroachment, but never in advance. The effectiveness of homegrown security, we can say, was low, rather due to the lack of weapons, lack of training, and lack of relevant experience. This weakness was emphasized by most witnesses. The only exceptions were the Red Army units in the workers' districts. The low fighting qualities of protective groups were explained by the fact that both representatives of the same social groups, and sometimes the same people, were robbing and protecting people. In general, the organization of self-protection, supported both from a top and a bottom, became a natural reaction of society to the growth of anarchy and, despite its numerous costs, brought serious positive results.

One of the examples of inertia of social development could be the development of the sector of leisure of urban residents. This sector has remained traditional, with the exception of attempts by authorities and public to fill certain areas with revolutionary or national content. The search for innovative forms in art, characteristic of any revolution, was carried out mainly in the way of previous approaches. Characteristically 
there was a desire of individual representatives of the intelligentsia to preserve cultural habits as a way to stay themselves, to guarantee the stabilization of their worldview. The autonomy of the leisure sector was confirmed, firstly, by the predominantly apolitical nature of artists and, secondly, by the functioning of cultural institutions even in the conditions of a transitional period between different authorities.

In 1917-1920 cinema and theater, both professional and amateur, performed several functions. First, they were a kind of abstraction from reality, made it possible to create some kind of imaginative world to hide in it from the reality. Secondly, they were a source of income for artistic groups and technical staff. Thirdly, theater and cinema were a propaganda tool that was actively used by the Bolsheviks. And finally, it was a way of entertainment in the context of a shortage of other entertainments, a channel of joining to cultural values. The Bolsheviks sought to nationalize theaters and cinema, limiting entrepreneurial activity. The White Guards left theatrical and cinematographic sphere for private initiative, but sometimes they were doing a confiscation of the relevant buildings and premises for wartime needs.

The activitiy of theaters and cinema was actively used in charity, either in the form of mark-ups for tickets, or in the form of discount tickets for certain categories of viewers, or, most often, for charity events - performances, concerts, and a actor groups gathering. Recipients of charitable assistance were educational institutions, people with disabilities, including war invalids, sick and wounded Red Army soldiers, mothers with small children. Theatrical buildings were also used for lecturing and performing a conferences, meetings, and celebrating calendar and memorable dates. The repertoire of theater and cinema was practically not updated compared to the pre-revolutionary times; classical plays were staged, with rare exceptions, when sometimes classic was replaced by political agitations on Soviet themes. The lack of films forced to demonstrate the old tape, passed on, so-called, from hand to hand.

Musical groups and individual performers were not less popular than theaters and cinemas. The performance of Russian and foreign composers' concerts, according to contemporaries, was causing a transfiguration of the public. The painting experienced a shortage of materials due to the high cost, faced with certain financial difficulties. The folk libraries (in the villages — reading rooms) worked throughout the 
civil war, their number diminished, then increased, but never fell to zero. Under Soviets, the libraries were under the administration of the departments of public education, under other regimes they were controlled by zemstvos, cooperatives, and rural communities. New books were received in insignificant quantities only in 1917-1918, later there was no new books received at all, so it was necessary to protect them by any means, and to restore the old funds. Newspapers came as soon as were published, only their content changed - depending on the ruling political power. Certain events were held in the sports field and other forms of leisure. In general, the development of culture was carried out in 19171920 in traditional forms, filled with occasional new content.

Trade was developing in conditions of not only armed confrontation, but also under the prohibitive policy of central and local authorities. Economic separatism of individual regions of one state, as always in a crisis, preceded political separatism. Governmental bans in the trade sphere were supported by mass public attitudes, which required equal distribution of goods in the conditions of shortage. The population under Bolsheviks relied solely on requisitioning practice.

Nonetheless, a private trade turned out to be an absolutely natural experience, which was based on a developed social division of labor. Without a wide distribution of private trading operations many people simply would not have survived. Even the Bolsheviks were in need of private trading in conditions of collapse of the economic mechanism. The imperfection of the public supply was compensated by private initiative. The fight against speculation led only to higher prices. Entrepreneurial citizens found the most exotic ways to overcome the prohibitions. Direct barter prevailed in international trade. The supply of workers became an own job of each manufacture.

The market was an indicator of the state of society. It would be suspended at the slightest threat, and re-started at the minimal opportunity, as a life arises without any outside interference, when the necessary conditions of it occur. The market during the civil war clearly demonstrated the essence of money as a result of a public agreement, because without some equivalent, only through a direct exchange, trade could not exist. Naturally, the money course was determined solely by the traders of goods. The social composition of sellers and buyers, the quantity and range of goods, the most popular monetary kinds, even the 
appearance of markets' visitors, differed significantly in different years of revolution, and made it possible to accurately evaluate the situation in a city, region, or country.

N.B. Lebina and A.N. Chistikov argued that the profession of ragman in the era of the civil war was revived only with the restoration of commodity-money relations. In the markets of Ukrainian cities, commodity-money relations never disappeared, various monetary units were in use even under the Bolsheviks. Barter existed simultaneously and in parallel. The profession of the ragman has the same permanence, and was mastered by the representatives of the privileged class of society.

In historiography, there is a prevailing feature of everyday life such as a recurrence of the same events that requires a response to the actions risen to automatism. A feature of everyday life of citizens in the conditions of revolution and civil war was the repeatability of the unrepeatable. And the needs of people, regularly arising and constantly existing, could be considered a repeatable phenomenon of everyday life in 1917-1920. The ways of their satisfaction in some cases could be unique, but always unexpected.

For example, the constant need for food could be satisfied in many ways. Those could be: getting a bread after a long standing in the "tail", exchanging the household utensils to food, earning food in the village, growing in the own garden, buying for some money that was in use in the market. It was possible to have lunch in the public canteens, to get a job as a Soviet employee and get the right to have a food ration. In the end, sometimes there was an opportunity to get a charity bowl of soup, or, as an exception, to get to a banquet in a rich house. In the same way, the constant need for clothes was realized by buying, occasionally, by private sewing from the textile received for the coupon, by renewing the old dress, by receiving confiscated items on a Soviet basis, by a military warehouse marauding, or even by removing clothes from those who were killed.

If you try to classify that society by means of livelihood, then all urban residents can be divided into three groups. Representatives of the first group, the most wealthy in comparison to others, had the opportunity to earn their money in the old manner, providing services according to their specialty. This group included tailors, shoemakers, furnace workers, and other specialists in the service sector. And they could earn only if they

\footnotetext{
5 Лебина Н. Б. Чистиков А.Н. Обыватель и реформы. Картины повседневной жизни горожан в годы нэпа и хрущевского десятилетия. - С. 114-115.
} 
had a full set of necessary tools, as well as at least a minimum stock of materials. The second group, which included those with professions of little or no demand, who in the conditions of revolution and war, got new specialties, including unskilled works, in order to provide a goods for themselves and their families. These were former soldiers who did not want to take up weapons again, lawyers who were out of work after the destruction of the previous legal system, and officials of the disappeared administrative structures. They worked in delivery services, in firewood sawing, in cleaning the streets. The position of art workers was ambiguous. Sometimes they managed to find work in their specialty, particularly, by organizing tours, but mostly used to have an odd jobs. Finally, the third group did not try to solve their problems on their own, and turned to the authorities for help, in the best way starting to work in the service of this authority. The category of dependents in the total civilian population kept rising steadily as a result of the gradual destruction of the economy. Such a transformation of the social structure increased the pressure on the state mechanism, which was forced to satisfy the needs of the mass of people. By and large, the majority of ordinary citizens were not interested in the nature of power, and even less interested in its political overtones.

The system crisis determined the crisis of working nature of representatives of all sectors of society. A common consequence of the chaos caused a significant narrowing of professional activities. The nature of work and the nature of payment have changed. The usual economic incentives of labor, which returned to the most primitive forms, have lost their force.

\section{CONCLUSION}

Hunger, devastation, endless war brought the population of cities to the threshold beyond which was the complete disintegration of society and mass death. The heightening of fighting operations was reflected in the attitude of the military people towards civilians, the tiredness of both those and others from the long war sometimes led to unmotivated aggression. The constant external insecurity caused apathy and indifference, the wishes of order and rules were accumulated from endless anarchy. 
The most striking features of public spirit were changes in the ideological and political views of the population, the destruction of social class characteristics, desires and expectations of certain social groups, the loss of legitimate levers of regulation of social processes. The society in a state of permanent transformation was characterized not only by changes in the public awareness, but by a gradual increase in its chaos and eclecticism.

The level of public claims to power has noticeably decreased, almost the only one requirement was to stabilize the situation. All other needs were derived. This state of society has prepared the psychological ground for the final victory of the Red Army, as the most massive and disciplined armed forces.

Only the Bolsheviks could give society hope for the future, even if only in a form of a guaranteed minimum of food and order on the streets, provided with total terror. Thus, it was not an ideological myth that won the civil war, but food ration and Mauser.

Ukraine resisted the decaying influence of the global crisis longer than most Russian provinces. The limit of social resistance was reached only in the winter of 1919-1920, when all social reserves were exhausted. After that, the restoration of the former social relations became impossible, firstly, because most of the carriers of these relations died out or stayed in internal or external emigration, and secondly, because the will of people to resist was undermined due to the hunger.

Thus, all obstacles to the establishment of the Bolshevik dictatorship in the cities were eliminated. Cities were defenseless in front of the most insane social experiments. The new economic policy was implemented in a centralized way, and its termination did not cause organized mass protests. The hunger-time in the urban environment had place during the period of the civil war, and affected all social classes, including the workers. The village did not suffer, it survived the war quite well, and therefore, in order to neutralize the peasantry, a second period of hunger was needed, and this time it was organized from the beginning to the end.

Only a tough, cruel, centralized state could win the turmoil and overcome anarchy of civil war. Such a victory had far-reaching consequences. People were accustomed to cruelty, accustomed to fear of the state machine. At the same time, it turned out to be a very convenient opportunity to shift to the state responsibilities not only the concerns 
about their own safety, but also the solutions of many other problems, including domestic ones. The nationalization of all aspects of life destroyed the germs of civil society in Ukraine. When everything began to be provided by the state, it got the opportunity to take it all back without fear of open disagreements. The civil war pushed our country onto the Asian path of political development, turned its surviving citizens into dependents, without a sense of freedom and a sense of responsibility. And only now we are struggling to get out of the psychological heritage of the civil war, very slowly, with hesitations and deviations, joining the European values.

\section{SUMMARY}

Events of 1917-1920 in the cities of Ukraine demonstrated, firstly, the fantastic ability of ordinary inhabitants to survive; secondly, a clear division of society into two groups depending on the style of behavior in extreme conditions. The first group of citizens tried to earn their own livelihood, and belonging to this group did not depend on social status. In the second group, dependent moods prevailed. This category of citizens was the main support and personnel reserve for the Soviet government.

The crisis put society in front of the need to rigidly determine priorities in meeting their needs. The attributes of everyday life in extreme conditions were social inertia manifested in the ability of social structures and individuals to maintain the usual forms of interaction in a changing situation; social mimicry as a conscious change in appearance, as a way to dissolve in a democratic environment; and social revenge, as a form of revenge for previously privileged groups of the population.

\section{REFERENCES}

1. Борисенко М. В. Житло та побут міського населення України у 20-30-х рр. ХХ століття. - К.: ВД «Стилос», 2013. - 270 с.

2. Шкляев И. Н. Одесса в смутное время. - Одесса: Изд. центр «Студия «Негоциант», 2004. - 158 с.

3. Нарский И.В. Жизнь в катастрофе: Будни населения Урала в 1917-1922 гг. - М.: Российская политическая энциклопедия, 2001. $632 \mathrm{c}$.

4. Ильюхов А.А. Жизнь в эпоху перемен: Материальное положение городских жителей в годы революции и гражданской 
войны (1917-1921 гг.). - М.: Российская политическая энциклопедия, 2007. -264 c.

5. Лебина Н. Б. Обыватель и реформы. Картины повседневной жизни горожан в годы нэпа и хрущевского десятилетия / Н.Б. Лебина, А.Н. Чистиков. - СПб.: Изд-во «Дмитрий Булавин», 2003. - $340 \mathrm{c}$.

\section{Information about the authors:} Popov V. Z. dr. history sciences, professor V.I. Vernadsky Taurida National University 01133, Ukraine, Kyiv, 33 Ivana Kudry Str. 